\title{
EFEKTIFITAS AKTA YANG MEMUAT KLAUSULA ACCESOIR DALAM UPAYA MEMBERIKAN PERLINDUNGAN HUKUM BAGI NOTARIS
}

\author{
Dudi Setiyawan \\ Bank Panin Dubai Syariah Cabang Malang \\ Jalan Mayor Sugiono Pranoto No. 7 Kota Malang \\ Email: dsetiyawan55@gmail.com
}

\begin{abstract}
Abstrak
Kedudukan hukum terhadap akta yang memuat klausula accesoir dalam rangka memberikan perlindungan hukum bagi profesi Notaris merupakan akta yang autentik. Penambahan kalusula accesoir tersebut tidaklah bertentangan dengan peraturan manapun, termasuk UUJN. Penambahan kalusula accesoir dapat dimasukkan kedalam akta selama dibatas wajar (tidak berlebihan) dan diketahui serta disetujui oleh para pihak yang menghadap, sehingga kedudukan akta tersebut tetaplah menjadi akta yang autentik yang menjadikannya produk hukum yang sempurna sebagai alat bukti.
\end{abstract}

Kata kunci: akta notaris, perlindungan hukum, efektifitas

\section{Abstract}

The legal position of the act containing the accesoir clause in order to provide legal protection for the notary profession is an authentic act. The addition of the accesoir case is not contrary to any rules, including the UUJN. The addition of accesoir can be incorporated into the deed as long as it is reasonable (not exaggerated) and acknowledged and approved by the parties facing it, so the position of the act remains an authentic act which makes it a legal product perfect as a means of proof.

Keywords: notary deed, legal protection, effectiveness

\section{PENDAHULUAN}

Notaris adalah pejabat umum (openbaar ambtenaar) yang satusatunya berwenang untuk membuat akta-akta tentang segala tindakan, perjanjian serta suatu keputusan-keputusan tertentu yang oleh perundangundangan umum diwajibkan, atau kehendak dari para pihak yang bersangkutan agar dinyatakan dalam suatu akta otentik. Menetapkan tanggalnya, menyimpan aktanya dan memberikan grosse (salinan sah), salinan dan kutipan, semuanya itu sepanjang pembuatan akta-akta tersebut tidak juga diwajibkan kepada pejabat atau khusus menjadi kewajibannya. 
Berdasarkan Undang-Undang Nomor 02 Tahun 2014 tentang Perubahan Atas Undang-Undang Nomor 30 Tahun 2004 tentang Jabatan Notaris (selanjutnya disebut dengan UUJN), Pasal 1 ayat (1) yang menentukan sebagai berikut : "Notaris adalah pejabat umum yang berwenang untuk membuat akta autentik dan memiliki kewenangan lainnya sebagaimana dimaksud dalam undang-undang ini atau berdasarkan undang-undang lainnya". Menurut R. Soegondo Notodisoerjo, Notaris adalah pejabat umum openbare ambtenaren, karena erat hubungannya dengan wewenang atau tugas dan kewajiban yang utama yaitu membuat akta-akta otentik. $^{1}$

Menurut Habib Adjie, Notaris merupakan suatu jabatan publik yang mempunyai karakteristik yaitu sebagai jabatan. UUJN merupakan unifikasi di bidang pengaturan jabatan Notaris, artinya satu-satunya aturan hukum dalam bentuk undang-undang yang mengatur jabatan Notaris di Indonesia sehingga segala hal yang berkaitan dengan jabatan Notaris di Indonesia harus mengacu kepada UUJN. Jabatan Notaris merupakan suatu lembaga yang diciptakan oleh Negara. Menempatkan Notaris sebagai pejabat umum merupakan suatu bidang pekerjaan atau tugas yang sengaja dibuat oleh aturan hukum untuk keperluan, fungsi dan kewenangan tertentu serta bersifat berkesinambungan sebagai suatu lingkungan pekerjaan tetap. ${ }^{2}$

Permasalahan sebagaimana tersebut diatas pernah dialami oleh Notaris BS (inisial) sebagai Notaris/PPAT yang memiliki wilayah kerja di Kabupaten Malang. Beliau menyatakan bahwa dalam pembuatan akta Notaris yang pada saat itu dipermasalahkan telah melalui prosedur yang benar, menuangkan seluruh kehendak para pihak tanpa adanya intervensi apapun dari pihak ketiga atau Notaris itu sendiri, namun beliau mengatakan bahwa akta yang telah dibuat tersebut ternyata tidak cukup mampu melindungi Notaris dari iring-iringan permasalahan hukum yang ditimbulkan dari para pihak hingga pada proses peradilan. ${ }^{3}$

Melihat kondisi tersebut di atas, tidak sedikit Notaris yang kemudian melakukan antisipasi untuk menghindari kriminalisasi Notaris dengan cara menambahkan klausula pada akhir akta otentik dengan salah satu contoh inti frasanya yaitu: "apabila terjadi sengketa dikemudian hari terhadap isi akta, maka dengan ini para penghadap sepakat untuk tidak melibatkan Notaris sebagai pihak dalam sengketa. Contoh klausula tersebut merupakan suatu

${ }^{1}$ R. Soegondo Notodisoerjono, Hukum Notariat di Indonesia Suatu Penjelasan, (Jakarta: Raja Grafindo Persada,1993), hal. 8

2 Habib Adjie, Sanksi Perdata dan Administratif Terhadap Notaris sebagai Pejabat Publik, (Bandung: Refika Aditama, 2008), hlm. 32-34

${ }^{3}$ Hasil wawancara dengan Notaris BS (inisial) di Kabupaten Malang, 14 April 2019. 
bentuk klausula tambahan yang dapat dibubuhi di dalam akta oleh Notaris, yang sifatnya tentu tidaklah wajib karena tidak diatur secara pasti didalam peraturan jabatan Notaris atau UUJN.

Berdasarkan hasil penulusuran penulis guna menunjang data pendahuluan pada penulisan hukum ini, telah diketahui bahwa terdapat beberapa kasus yang terjadi terkait dengan penambahan klausula accesoir dalam akta selama kurang lebih 3 tahun terakhir, khususnya di Kabupaten Malang. Penambahan dan tidaknya suatu klausula accesoir dalam kasus tersebut turut menentukan tahapan proses hukum yang dijalani oleh Notaris yang bersangkutan. ${ }^{4}$

Bilamana dikemudian hari penambahan klausula accesoir ini dirasa penting guna melindung profesi Notaris, maka perlu kiranya untuk ditinjau dan dianalisis lebih lanjut mengenai tingkat efektifitas dan kepastian hukum yang dapat diberikan guna meminimalisir terjadinya kriminalisasi pada profesi Notaris.

\section{METODE PENELITIAN}

Dalam penelitian ini, jenisnya adalah yuridis empirik dengan pendekatan sosiologis dan studi kasus, teknik pengambilan bahan yang digunakan adalah teknik wawancara, dokumentasi, dan pengamatan, sumberdatanya dari informan di lapangan dan bahan hukumnya menggunakan bahan hukum primer dan sekunder. Sedangkan analisisnya menggunakan deskriptif kualitatif.

\section{PEMBAHASAN}

\section{Gambaran Umum Lokasi Penelitian}

Kabupaten Malang merupakan salah satu Kabupaten yang ada di provinsi Jawa Timur, kabupaten Malang adalah kabupaten terluas kedua di jawa timur setelah kabupaten banyuwangi dan merupakan kabupaten dengan populasi terbesar di jawa timur.secara geografis terletak antara 112,17', 112,57" Bujur Timur dan 7,44"-8,26" Lintang Selatan. Batas wilayah Kabupaten Malang adalah sebagai berikut: Kabupaten Jombang, Kabupaten Pasuruan dan kota batu, di utara kabupaten lumajang dan kabupaten Probolinggo di timur, Samudra Hindia di selatan. Sebagian besar wilayahnya merupakan pegunungan yang berhawa sejuk, kabupaten malang terkenal sebagai salah satu daerah tujuan wisata utama di jawa timur bersama dengan kota malang dan kota batu, kabupaten malang merupakan bagian dari kesatuan wilayah yang dikenal dengan malang raya (wilayah metropolitan Malang) Hal tersebut sangat menguntungkan untuk

${ }^{4}$ Hasil wawancara dengan Notaris MKN di Kabupaten Malang, 13 April 2019 
pengembangan ekonomi dan membuka peluang investasi ${ }^{5}$ bagi Kabupaten Malang.

Secara keseluruhan luas wilayah Kabupaten Malang yakni 2.475,680. Km2. Kabupaten ini terdiri dari 33 Kecamatan, yang dibagi habis dalam 12 Kelurahan dan 378 Desa.

"Satata Gama Karta Rahardja" adalah motto pembangunan yang dipilih Kabupaten Malang. Makna yang terkandung dalam motto tersebut adalah Menata semua untuk kesejahteraan.

Makna tersebut dapat dibaca dari komposisi gambar dan warna yang terdapat pada lambang daerah kabupaten Malang. Perisai segi lima dengan garis tepi tebal berwarna merah putih melambangkan jiwa nasional bangsa indonesia yang suci dan berani, dimana segala usaha ditujukan untuk kepentingan nasional berlandasan falsafah Pancasila, kubah melambangkan mencerminkan papan atau tempat bernaung bagi kehidupan rohani dan jasmani di ruang lingkup daerah kabupaten malang, bintang bersudut lima melambangkan mencerminkan keutuhan yang maha esa berdasarkan falsafah pancasila yang luhur dan agung, untaian padi melambangkan menerminkan potensi alam daerah, daun kapas melambangkan semangat perjuangan, rantai melambangkan persatuan dan keadilan, asap melambangkan semangat yang tak pernah kunjung padam, laut melambangkan kekayaan alam yang ada dikabupaten malang, keris melambangkan cita-cita yang abadi dan tak pernah padam, keris melambangkan jiwa kepahlawanan dan kemegahan sejarah daerah kabupaten malang, buku terbuka melambangkan kecerdasar rakyat untuk kemajuan.

Pemilihan gambar ini tidak serta merta dipasang begitu saja, melainkan sebagai cerminan realitas kehidupan masyarakat Kabupaten Malang yang sebagian besar memiliki tradisi yang kental dengan kerajaannya Singhasari.

Perisai segi lima, kubah gunung merapi, asap, keris,buku terbuka, laut, gelombang laut, butir padi, bunga kapas, daun kapas, bintang bersudut lima, rantai, melambangkan bahwa kondisi geografis Kabupaten Malang secara khusus sangat strategis dan terletak diantara ketiganya yang masingmasing mengandung potensi perekonomian yang dapat dikembangkan dan bersifat dinamis. Gambar ini mencerminkan bahwa letak kabupaten malang memang sangat strategis berada di jalur segi tiga pusat pertumbuhan

${ }^{5}$ Hasil penelitian Komite Pemantauan Pelaksanaan Otonomi Daerah (KPPOD), tahun 2002 Kabupaten Malang menduduki peringkat ke 56 dari 134 Kabupaten dan Kota yang menjadi daya tarik investasi. Peringkat daya tarik investasi tersebut lebih baik dari pada tahun 2001 di mana Kabupaten Malang berada pada peringkat ke 53 dari 90 Kabupaten dan Kota.Lihat: Rencana Strategis Kabupaten malang 2003-2008, hal. 40 
ekonomi propinsi Jawa Timur yaitu Surabaya Malang raya. Dengan demikian, peluang untuk menciptakan pertumbuhanekonomi, potensi dan investasi yang dimiliki daerah ini sangatlah besar khususnya sektor pertanian, perkebunan, perikanan, peternakan, kerajinan, industri dan pariwisata.

\section{Kedudukan Hukum Terhadap Akta Yang Memuat Klausula Accesoir Dalam Rangka Memberikan Perlindungan Hukum Bagi Profesi Notaris}

Kedudukan hukum yang menjadi fokus pembahasan pada subbab penulisan hukum ini berkaitan dengan hukum pembuktian, mengingat akta Notaris merupakan salah satu alat bukti yang sempurna, khususnya dalam proses persidangan dalam suatu sengketa perdata, sehingga dalam hal ini akan dikaji terkait implikasi hukum bilamana suatu akta tersebut terdapat klausula accesoir yang belum/tidak diatur didalam suatu perundangundangan, termasuk UUJN. Menurut A.Pitlo akta itu sebagai surat-surat yang ditandatangani, dibuat untuk dipakai sebagai bukti, dan dipergunakan oleh orang, untuk keperluan siapa surat itu dibuat. Kemudian menurut Sudikno MertoKusumo akta adalah surat yang diberi tanda tangan, yang memuat peristiwa-peristiwa, yang menjadi dasar dari suatu hak atau perikatan, yang dibuat sejak semula dengan sengaja untuk pembuktian. ${ }^{6}$

Pada dasarnya akta notariil dibuat berdasarkan suatu perjanjian yang yang disepakati oleh para pihak/penghadap. Menurut R. Subekti, suatu perjanjian merupakan suatu peristiwa dimana seseorang berjanji kepada orang lain, atau di mana dua orang saling berjanji untuk melaksanakan sesuatu hal. ${ }^{7}$ Kemudian R. Setiawan, menyebutkan bahwa perjanjian ialah suatu perbuatan hukum di mana satu orang atau lebih mengikatkan dirinya atau saling mengikatkan dirinya terhadap satu orang atau lebih. ${ }^{8}$ Begitu juga Sri Soedewi Masjchoen Sofwan, berpendapat bahwa perjanjian merupakan perbuatan hukum dimana seseorang atau lebih mengikatkan dirinya terhadap seorang lain atau lebih. ${ }^{9}$

Menurut buku ke III Kitab Undang-Undang Hukum Perdata (selanjutnya disebut KUHPerdata), dalam Pasal 1313 dikatakan perjanjian sebagai suatu perbuatan dimana satu orang atau lebih mengikatkan diri

hal 1

${ }^{6}$ Daeng Naja, Teknik Pembuatan Akta, (Yogyakarta: Pustaka Yustisia, 2012),

${ }^{7}$ R. Subekti, Pokok-Pokok Hukum Perdata, )Jakarta: PT. Intermasa, 2001), hal. 36 Cipta, 1987),

8 R. Setiawan, Hukum Perikatan-Perikatan Pada Umumnya, (Bandung: Bina hal. 49

${ }^{9}$ Sri Soedewi Masjchoen Sofwan, Hukum Jaminan di Indonesia Pokok-Pokok Hukum Jaminan dan Jaminan Perorangan, (Yogyakarta: Liberty, 1980), hal. 1. 
terhadap satu orang lain atau lebih. Dalam hal ini, sebuah perjanjian menjadi sumber dari terjadinya perikatan tersebut.

Perikatan yang lahir karena perjanjian mempunyai akibat hukum yang memang dikehendaki oleh para pihak, karena memang perjanjian didasarkan atas kesepakatan para pihak. Sedangkan perikatan yang lahir dikehendaki oleh para pihak, tetapi hubungan hukum dan akibat hukumnya ditentukan oleh undang-undang. ${ }^{10}$ Perjanjian atau Verbintenis adalah suatu hubungan hukum kekayaan/harta benda antara dua orang atau lebih, yang memberi kekuatan hak pada satu pihak untuk memperoleh prestasi dan sekaligus mewajibkan pada pihak lain untuk menunaikan prestasi.

Terhadap uraian pengertian singkat di atas dapat diketahui bahwasanya terdapat beberapa unsur yang memberi wujud pengertian perjanjian, antara lain yaitu hubungan hukum yang menyangkut hukum kekayaan antara dua orang atau lebih, yang memberi hak pada satu pihak dan kewajiban pada pihak lain tentang suatu prestasi. Maka dengan demikian, perjanjian adalah hubungan hukum yang oleh hukum itu sendiri diatur dan disahkan cara perhubungannya. Oleh karena itu perjanjian yang mengandung hubungan hukum antara perorangan adalah hal-hal yang terletak dan berada dalam lingkungan hukum.

Ketentuan mengenai kewenangan Notaris untuk membuat akta otentik diatur dalam Pasal 1 Undang-Undang No. 30 Tahun 2004 tentang Jabatan Notaris sebagaimana telah diubah dengan Undang-Undang No. 2 Tahun 2014 (UUJN), yang disebutkan bahwa Notaris merupakan pejabat umum, yang berwenang untuk membuat akta otentik dan memiliki kewenangan lainnya sebagaimana dimaksud dalam UU ini atau berdasarkan UU lainnya.

Pemahaman mengenai akta Notaris dapat diketahui di dalam Pasal 1868 KUHPerdata yang menyebutkan bahwa : "Suatu akta otentik adalah suatu akta yang dibuat dalam bentuk yang ditentukan oleh Undang-Undang oleh atau di hadapan pejabat umum yang berwenang untuk itu di tempat akta itu dibuat". Salah satu hal yang perlu diperhatikan sebelum masuk kepada esensi dari akta Notaris berdasarkan pasal 1868 KUHPerdata tersebut adalah adanya frasa "di tempat dimana akta dibuat", hal tersebut harus diperhatikan karena berhubungan dengan tempat kedudukan Notaris, bahwa Notaris mempunyai tempat kedudukan di wilayah kabupaten atau kota (Pasal 18 ayat (1) UUJN). Wilayah jabatan Notaris meliputi seluruh wilayah provinsi dari tempat kedudukannya (Pasal 18 ayat (2) UUJN). Maka dapat diambil kesimpulan bahwa Notaris tidak berwenang dan tidak diperbolehkan membuat akta diluar dari wilayah kerjanya.

${ }^{10}$ Suharnoko, Hukum Perjanjian (Teori dan Analisa Kasus), Edisi 1 Cetakan ke-4, (Jakarta: Kencana Prenada Media Group, 2004), hal. 115 
Akta Notaris dalam Pasal 1 angka 7 UUJN, dimaknai sebagai akta otentik yang dibuat oleh atau di hadapan Notaris, menurut bentuk dan tata cara yang ditetapkan dalam UU ini. Secara gramatikal, dalam Kamus Besar Bahasa Indonesia, akta dimaknai sebagai surat tanda bukti berisi pernyataan (keterangan, pengakuan, keputusan, dsb) tentang peristiwa hukum yang dibuat menurut peraturan yang berlaku, disaksikan dan disahkan oleh pejabat resmi.

Perihal frasa "menurut bentuk dan tata cara yang ditetapkan dalam UUJN" sebagaimana yang dinyatan dalam Pasal 1 angka 7 UUJN menjadi garis besar dan acuan bagi Notaris dalam melahirkan akta-aktanya. Maksud daripada "bentuk" merupakan susunan dari pada tubuh akta itu sendiri, adapun bagian-bagian dari tubuh akta tersebut telah diatur didalam Pasal 38 UUJN yang dijabarkan sebagai berikut :

a. Setiap akta Notaris terdiri atas :

1. awal Akta atau Kepala Akta;

2. badan Akta; dan

3. akhir atau penutup Akta.

b. Awal Akta atau Kepala Akta memuat :

1. Judul Akta;

2. Nomor Akta;

3. Jam, hari, tanggal, bulan, dan tahun ; dan

4. Nama lengkap dan tempat kedudukan Notaris.

c. Badan Akta memuat :

1. Nama lengkap, tempat dan tanggal lahir, kewarganegaraan, pekerjaan, jabatan, kedudukan, tempat tinggal para penghadap dan/atai orang yang mereka wakili;

2. Keterangan mengenai kedudukan bertindk penghadap;

3. Isi Akta yang merupakan kehendak dan keinginan dari pihak yang berkepentingan; dan

4. Nama lengkap, tempat dan tanggal lahir, serta pekerjaan, jabatan, kedudukan, dan tenpat tinggal dan tiap-tiap saksi pengenal.

d. Akhir atau pentutup Akta memuat:

1. Uraian tentang pembacaan Akta sebagaimana dimaksud dalam Pasal 16 ayat (1) huruf $m$ atau Pasal 16 ayat (7);

2. Uraian tentang penandatanganan dan tempat penandatanganan atau penerjemah Akta jika ada;

3. Nama lengkap, tempat tanggal lahir, dan pekerjaan, jabatan, kedudukan, dan tempattinggal dari tiap-tiap saksi Akta; dan

4. Uraian tentang tidak adanya perubahan yang terjadi dalam pembuatan Akta atau uraian tentang adanya perubahan yang dapat berupa penambahan, pencoretan, atau penggntian serta jumlah perubahan. 
Sebagaimana hasil yang telah ditemukan oleh penulis dalam tinjauan empirisnya telah ditemukan beberapa akta Notaris yang menggunakan klausula accesoir, dengan maksud agar kalausula accesoir tersebut dapat meminimalisir tindakan kriminalisasi terhadap Notaris. Temuan tersebut diketahui terdapatnya klausula accesoir pada bagian akhir dari badan akta, yang mana temuan tersebut akan penulis cantumkan pada bagian pembahasan rumusan masalah yang kedua dalam penulisan hukum ini.

Penambahan klausula accesoir sebagaimana hasil dari penulusuran penulis terhadap Notaris-Notaris yang bersangkutan, diketahui bahwa penambahan klausula accesoir tersebut merupakan inisiatif dari beberapa Notaris yang tidak ingin bersinggungan dengan persoalan hukum yang terjadi kemudian hari diantara para kliennya yang telah membuat akta tersebut. Oleh karena penambahan kalusula accesoir tersebut tidak diatur dalam peraturan perundang-undangan maka yang menjadi pertanyaan adalah, apakah akta tersebut tetap menjadi akta autentik atau menjadi akta dibawah tangan, mengingat Pasal 41 UUJN mengatakan bahwa "Apabila ketentuan dalam Pasal 39 dan Pasal 40 tidak dipenuhi, akta tersebut hanya mempunyai kekuatan pembuktian sebagai akta di bawah tangan".

Adapun aturan UUJN yang mengatur isi daripada badan akta berdasarkan Pasal 38 ayat 3 menyatakan bahwa badan akta haruslah memuat: nama lengkap, tempat dan tanggal lahir, kewarganegaraan, pekerjaan, jabatan, kedudukan, tempat tinggal para penghadap dan/atau orang yang mereka wakili; keterangan mengenai kedudukan bertindak penghadap; isi akta yang merupakan kehendak dan keinginan dari pihak yang berkepentingan; dan nama lengkap, tempat dan tanggal lahir, serta pekerjaan, jabatan, kedudukan, dan tempat tinggal dari tiap-tiap saksi pengenal.

Jelas kiranya bahwa tidak ada satupun didalam Pasal tersebut diatas yang memberi ruang agar Notaris dapat memberikan klausula accesoir pada produk aktanya, namun berdasarkan hasil wawancara bersama salah satu Notaris/PPAT senior di Kabupaten Malang menyatakan bahwa $:{ }^{11}$ penambahan kalusula accesoir pada produk akta memang tidaklah diatur didalam UUJN atau peraturan perundang-undangan lainnya, namun juga tidak dilarang oleh peraturan manapun juga, artinya penambahan klausula accesoir tersebut dapat dimasukkan kedalam akta selama dibatas wajar (tidak berlebihan) dan diketahui serta disetujui oleh para pihak yang menghadap, sehingga akta tersebut tetaplah menjadi akta yang autentik.

\footnotetext{
${ }^{11}$ Hasil wawancara dengan Notaris AF (inisial) di Kabupaten Malang, 06 April
} 
berikut: ${ }^{12}$

Menurut C.A.Kraan, akta otentik mempunyai ciri-ciri sebagai

a. Suatu tulisan dengan sengaja dibuat semata-mata untuk dijadikan bukti atau suatu bukti dari keadaan sebagaimana disebutkan di dalam tulisan dibuat dan dinyatakan oleh pejabat yang berwenang. Tulisan tersebut turut ditandatangani oleh atau hanya ditandatangani oleh pejabat yang bersangkutan saja;

b. Suatu tulisan sampai ada bukti sebaliknya, dianggap berasal dari pejabat yang berwenang;

c. Ketentuan peraturan perundang-undangan yang harus dipenuhi; ketentuan tersebut mengatur tata cara pembuatannya (sekurangkurangnya memuat ketentuanketentuan mengenai tanggal, tempat dibuatnya akta suatu tulisan, nama dan kedudukan atau jabatan pejabat yang membuatnya);

d. Seorang pejabat yang diangkat oleh negara dan mempunyai sifat dan pekerjaan yang mandiri serta tidak memihak dalam menjalankan jabatannya;

e. Pernyataan atau fakta dari tindakan yang disebut oleh pejabat adalah hubungan hukum di dalam bidang hukum privat.

\section{Efektifitas Akta Yang Memuat Klausula Accesoir Dalam Rangka Melindungi Profesi Notaris Dalam Menjalankan Jabatannya}

Istilah efektivitas menurut Ensiklopedia Umum, ${ }^{13}$ berarti menunjukkan taraf tercapainya suatu tujuan. Suatu usaha dikatakan efektif apabila usaha itu mencapai tujuannya. Sedangkan dalam Kamus Umum Bahasa Indonesia, berarti pengaruh dari sesuatu, atau akibat tertentu dari sesuatu.

Suatu hal dapat dikatakan efektif apabila hal tersebut sesuai dengan dengan yang dikehendaki. Artinya, pencapaian hal yang dimaksud merupakan pencapaian tujuan dilakukannya tindak-tindakan untuk mencapai hal tersebut. Efektivitas dapat diartikan sebagai suatu proses pencapaian suatu tujuan yang telah ditetapkan sebelumnya. Suatu usaha atau kegiatan dapat dikatakan efektif apabila usaha atau kegiatan tersebut telah mencapai tujuannya. Apabila tujuan yang dimaksud adalah tujuan suatu instansi maka proses pencapaian tujuan tersebut merupakan keberhasilan dalam melaksanakan program atau kegiatan menurut wewenang, tugas dan fungsi instansi tersebut.

${ }^{12}$ Herlien Soerojo, Kepastian Hukum Hak Atas Tanah di Indonesia, (Surabaya: Arkola, 2003), hal. 148

13 Pringgodigdo, Ensiklopedia Umum, (Jakarta: Kencana Prenada Media Grup, 1991), hal. 45, 
Apabila keefektifan tersebut dikaitkan dengan hukum, maka perlu diketahui juga bahwa hukum yang hidup di masyarakat adalah hukum yang dilaksanakan dalam masyarakat sebagai hukum yang telah ditetapkan oleh Negara. Ehrlich lebih lanjut mengatakan, bahwa hukum tunduk pada ketentuan-ketentuan tertentu. Hukum sendiri tidak akan mungkin efektif oleh karena ketertiban pada pengakuan sosial terhadap hukum dan bukan pada penerapannya secara resmi oleh Negara. Bagi Ehrlich tertib sosial didasarkan fakta diterimanya hukum yang didasarkan pada aturan dan norma sosial yang tercermin dalam sistem hukum. Secara konsekuen ia beranggapan bahwa mereka yang berperan sebagai pihak yang mengembangkan sistem hukum harus mempunyai hubungan yang erat dengan nilai-nilai yang dianut dalam masyarakat yang bersangkutan. Kesadaran itu harus ada pada setiap anggota profesi hukum (termasuk Notaris) yang bertugas mengembangkan hukum yang hidup (living law), dan menentukan ruang lingkup hukum positif dalam hubungannya dengan hukum yang hidup. ${ }^{14}$

\section{KESIMPULAN}

Eksistensi atau kedudukan hukum terhadap akta yang dibuat Notaris yang memuat klausula accesoir dalam rangka memberikan perlindungan hukum bagi profesi Notaris merupakan akta yang autentik. Perlindungan yuridis ini identic sebagai bentuk pemberian jaminan kepastian hukum terhadap produk kinerja profesinya.

Penambahan kalusula accesoir tersebut tidaklah bertentangan dengan peraturan manapun, termasuk UUJN.Penambahan kalusula accesoir dapat dimasukkan kedalam akta selama dibatas wajar (tidak berlebihan) dan diketahui serta disetujui oleh para pihak yang menghadap, sehingga kedudukan akta tersebut tetaplah menjadi akta yang autentik yang menjadikannya produk hukum yang sempurna sebagai alat bukti untuk kepentingan apapun yang dibenarkan dalam peraturan perundang-undangan.

\section{DAFTAR PUSTAKA}

Daeng Naja, 2012, Teknik Pembuatan Akta, Yogyakarta: Pustaka Yustisia. Habib Adjie, 2008, Sanksi Perdata dan Administratif Terhadap Notaris sebagai Pejabat Publik, Bandung: Refika Aditama.

Herlin Soerojo, 2003, Kepastian Hukum Hak Atas Tanah di Indonesia, Surabaya: Arkola.

${ }^{14}$ Lili Rasjidi, Dasar-dasar Filsafat Hukum, (Bandung: Alumni, 1989), hal 
Pringgodigdo, 1991, Ensiklopedia Umum, Jakarta: Kencana Prenada Media Grup, 1991.

R. Setiawan, 1987, Hukum Perikatan-Perikatan Pada Umumnya, Bandung: Bina Cipta.

R. Soegondo Notodisoerjono, 1993, Hukum Notariat di Indonesia Suatu Penjelasan, Jakarta: Raja Grafindo Persada.

R. Subekti, 2001, Pokok-Pokok Hukum Perdata, Jakarta: PT. Intermasa

Sri Soedewi Masjchoen Sofwan, 1980, Hukum Jaminan di Indonesia PokokPokok Hukum Jaminan dan Jaminan Perorangan, Yogyakarta: Liberty.

Suharnoko, 2004, Hukum Perjanjian (Teori dan Analisa Kasus), Edisi 1 Cetakan ke-4, Jakarta: Kencana Prenada Media Group.

Lili Rasjidi, 1989, Dasar-dasar Filsafat Hukum, Bandung: Alumni. 